\title{
SCHACKOINELLA SPINA, A NEW BENTHIC FORAMINIFERAL SPECIES FROM COLD- WATER CORAL ECOSYSTEMS OF THE ALBORAN SEA AND THE GULF OF CÁDIZ
}

\author{
Claudio Stalder ${ }^{1,4}$, Flavius Székely-Szabolcs ${ }^{2}$, Akram El KateB ${ }^{1}$, David Van Rooij ${ }^{3}$ and Silvia Spezzaferri ${ }^{1}$
}

\section{ABSTRACT}

Schackoinella spina $\mathrm{n}$. sp. has been found in the eastern Alboran Sea at five different stations in water depths ranging from $258-330 \mathrm{~m}$, as well as in one $532 \mathrm{~m}$ deep station in the Gulf of Cádiz, north-eastern Atlantic Ocean. Three stations have been sampled with a giant box core (BC) and two stations with a gravity core (GC) system. The sediments of the BCs and the GCs are characterized by cold-water coral (CWC) debris and a high abundance of biogenic components (e.g., bryozoans, echinoderms, bivalves, gastropods, serpulids, foraminifera). The surface samples from the BCs were treated with an ethanol-rose Bengal solution following standardized sampling protocol. In the $\mathrm{BC}$ samples the specimens of Schackoinella spina $\mathrm{n}$. sp., were collected from the surface (0$1 \mathrm{~cm})$. In particular, one BC sample (MD13-3456BC) contained six live (stained) specimens and an abundance of non-stained specimens (46 per $50 \mathrm{~cm}^{3}$ sediment). The new species was found at several sediment depth intervals corresponding to a Holocene age.

The occurrence of this small $(60-140 \mu \mathrm{m})$ species in the Alboran Sea and Gulf of Cádiz has likely been overlooked in this region. Although not straightforward, the presence of this species in association with cold-water coral fragments and its absence in fine-grained pelagic sediments may indicate a relationship with this ecosystem.

\section{INTRODUCTION}

The European Atlantic continental margin is characterized by several thriving clusters or provinces of cold-water coral (CWC) reefs and mounds, where the azooxanthellate scleractinian corals Lophelia pertusa and Madrepora oculata proliferate and often build mound-like structures or reefs (Roberts et al., 2006; Henriet et al., 2014). Discoveries of new CWC ecosystems in the last two decades have fueled numerous studies on the various facets of these peculiar ecosystems, in particular, along the Atlantic and Mediterranean margins (e.g., Hovland et al., 1994; Van Rensbergen et al., 2005; Comas \& Pinheiro, 2008). In 2002, a research cruise of the R/V Belgica off Larache (Morocco) led to the discovery of mounds in water depths of 500-600 m, topping a cliff, the Pen Duick Escarpment in the El Arraiche Mud Volcano Field (Van Rensbergen et al., 2005; Van Rooij et al., 2011), which is characterized by the occurrence of CWC structures. In 2006, another CWC province was discovered off Melilla in the Alboran Sea, Western Mediterranean

\footnotetext{
${ }^{1}$ Department of Geosciences, University of Fribourg, Chemin du Musée 6, 1700 CH-1700 Fribourg, Switzerland

Babeş-Bolyai University, Faculty of Biology and Geology, Geology Department, Str. M. Kogâlniceanu 1, 400084 Cluj Napoca, Romania

${ }^{3}$ Ghent University, Department of Geology and Soil Science, Krijgslaan 281 S8, B-9000 Gent, Belgium

${ }^{4}$ Correspondence author: E-mail: claudio.stalder@unifr.ch
}

(Comas \& Pinheiro, 2008). Various sites were sampled in the Melilla Mounds Field (MMF) for the first time during the Training-Through-Research (TTR) cruise 17-Leg 1 (Comas et al., 2009). After these pioneering discoveries, several sites in the Gulf of Cádiz and Alboran Sea were discovered and sampled (Wienberg et al., 2009; Fink et al., 2013). The R/V Marion Dufresne MD194 "Gateways" cruise (10-21 June 2013) was carried out within the framework of the EU FP7 Eurofleets Program, aimed at investigating the CWCs on both sides of the Mediterranean-Atlantic gateway region.

Cold-water coral-reef development is strongly controlled by specific chemo-physical parameters, including water-mass density (Dullo et al., 2008), current velocity (Freiwald et al., 2004), and dissolved-oxygen concentrations (Davies et al., 2009; Fink et al., 2012). Recent studies (e.g., Duineveld et al., 2004, 2007; Kiriakoulakis et al., 2004) demonstrated CWC dependence on an abundant food supply. Cold-water coral ecosystems are unique because they host a highly diverse macrofauna from water depths ranging from $39 \mathrm{~m}$ down to several thousand meters (Freiwald et al., 2004).

Micropaleontological studies focusing on benthic foraminifera from CWC ecosystems published so far from the Norwegian shelf (e.g., Joseph et al., 2013; Spezzaferri et al., 2013; Stalder et al., 2014), the Porcupine Seabight and Rockall Trough (e.g., Rüggeberg et al., 2007; Margreth et al., 2009; Schönfeld et al., 2011; Smeulders et al., 2014), and the western Alboran Sea (Margreth et al., 2011) showed that the microfauna (benthic foraminifera) is also more diverse than in the surrounding environments. Based on live (stained) benthic foraminifera assemblages from CWC ecosystems, Margreth et al. (2009) and Spezzaferri et al. (2013) demonstrated that the relatively high diversity of the benthic foraminiferal fauna on reefs or mounds is related to enhanced food supply, to different sedimentary facies, and to increased availability of microhabitats (e.g., on coral branches). A recent comprehensive study of benthic foraminiferal assemblages from the Norwegian shelf, the Porcupine area (Seabight and Rockall Trough), and the Alboran Sea (Spezzaferri et al., in press) showed that benthic foraminiferal assemblages from CWC ecosystems are strongly homogeneous from the northeastern Atlantic to the western Mediterranean Sea.

However, considering the scarcity of detailed studies on benthic foraminifera associated with CWC reefs, there is a considerable lack of knowledge regarding their assemblage composition, microhabitat zonation and functioning, biotic interactions, feeding modes, and spatial distributions. Micropaleontological investigations can provide, as in this case, opportunities to find and describe new species. We propose here a new benthic foraminiferal species belonging to the poorly known genus Schackoinella Weinhandl, 1958, which was discovered in sediments from the Alboran Sea (eastern Mediterranean Sea) and the Gulf of Cádiz (Fig. 1A, Table 1). 
A
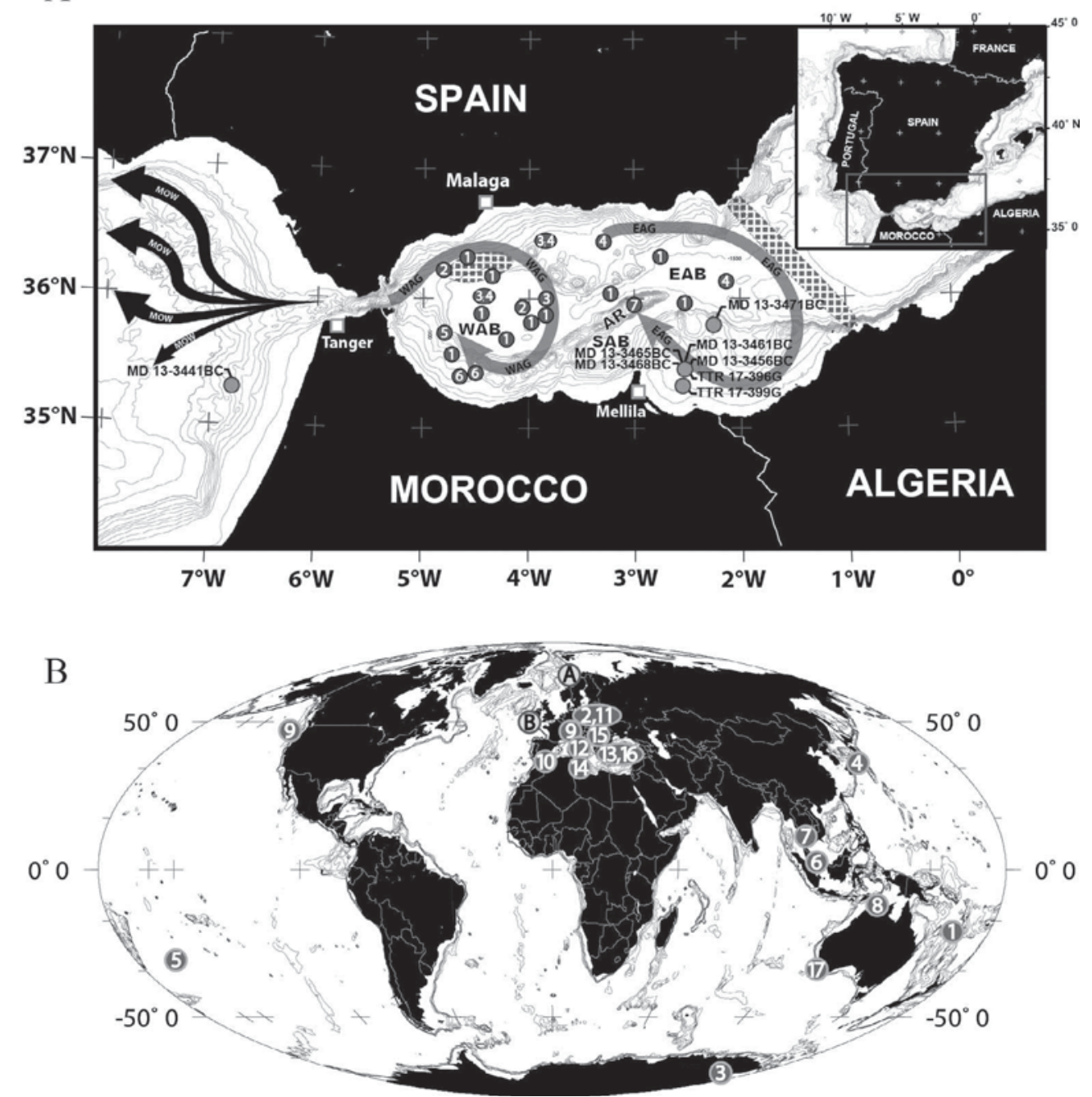

FIGURE 1. A Map of the Alboran Sea and the Gulf of Cádiz showing the location of the BC and GC samples recovered for this study (marked with sample label) and samples used for benthic foraminifera investigations in the Alboran Sea (numbers): 1, Auffret et al. (1974); 2, Cita \& Zocchi (1978); 3, Caralp (1988); 4, Vergnaud-Grazzini et al. (1989); 5, El Khanchoufi et al. (2000); 6, Margreth et al. (2011); 7, Milker \& Schmiedl (2012). Also shown: the Mediterranean Outflow Water (MOW), the Western Alboran Gyre (WAG), the Eastern Alboran Gyre (EAG), the Eastern Alboran Basin (EAB), the Western Alboran Basin (WAB), the Southern Alboran Basin (SAB), and the Alboran Ridge (AR). The two dashed areas show the locations of high primary productivity centers; B World map showing locations where species of the genus Schackoinella have been reported: 1, South of Grande Terre, New Caledonia (Debenay, 2012); 2, Poland (d'Orbigny, 1846); 3, McMurdo Sound and Island, Antarctica (Ward, 1987); 4, Off Honshu, Japan (McCulloch, 1977); 5, SW Pacific Ocean (Clark, 1994); 6, South China Sea (Culver et al., 2012); 7, Gulf of Thailand (Melis \& Violanti, 2006); 8, South Alligator River, Australia (Wang \& Chappell, 2001); 9, Gorda Bank, USA (McCulloch, 1977); 10, Mallorca Shelf and Alboran Ridge (Milker \& Schmiedl, 2012); 11, Tarnopol, Poland (Papp \& Schmid, 1985); 12, Gulf of Naples, Italy (Sgarella \& Moncharmont Zei, 1993); 13, Aegean Sea (Blanc-Vernet, 1969); 14, Kerkennah Isles, Tunisia (Blanc-Vernet et al., 1979); 15, Austria (Weinhandl, 1958); 16, Aegean and Levantine Seas (Abu-Zied et al., 2008) and 17, SW Australia (Quilty, 1975). Also displayed are areas where micropaleontological studies associated with CWC have been carried out: A, Norwegian Shelf; B, The Porcupine Seabight and Rockall Trough.

\section{Geologic And Oceanographic Settings}

The Alboran Sea is a $1,800 \mathrm{~m}$ deep basin located at the western part of the Mediterranean Sea, restricted to the north by the Iberian Peninsula, to its westernmost end by the Strait of Gibraltar, to the south by the African continent and to the east by the Algerian-Balearic Basin (Fig. 1A). The Alboran Sea is further subdivided into three basins, the eastern Alboran Basin (EAB), the western Alboran Basin (WAB) and southern Alboran Basin (SAB; Fig. 1A). The latter two are separated by a large NE-SW trending antiform, the Alboran Ridge (Comas et al., 1999).
Modern oceanographic conditions in the Alboran Sea have been extensively described by La Violette (1984), Parrilla et al. (1986), Heburn \& La Violette (1990), and Rohling et al. (1995), among others. The water-mass configuration is strongly related to the water exchange with the Atlantic Ocean through the Strait of Gibraltar and can be subdivided into three main water masses. The uppermost water mass (ca. 0-220 m) consists of Modified Atlantic Water (MAW), which is formed by a jet of Atlantic water passing through the Strait of Gibraltar and spawns two anticyclonic gyres in the Alboran Sea, the eastern Alboran Gyre (EAG) and the western Alboran Gyre 
TABlE 1. Station list of the BC and GC samples where $S$. spina Stalder \& Spezzaferri n. sp. have been found. The number of tests gives the abundance of dead (not stained) and live (stained) specimens in the BC (per $\sim 50 \mathrm{~cm}^{3}$ sediment) and GC samples (per $\sim 10 \mathrm{~g}$ of sediment). MMF $=$ Melilla Mounds Field; $\mathrm{BC}=$ Box core; $\mathrm{GC}=$ Gravity core; BSF = Below Sea-Floor.

\begin{tabular}{|c|c|c|c|c|c|c|c|c|c|}
\hline Station & Region & Lat. $\left({ }^{\circ} \mathrm{N}\right)$ & Long. $\left({ }^{\circ} \mathrm{W}\right)$ & Depth (m) & \# of tests & Sed. Facies & Gear & $\mathrm{BSF}(\mathrm{cm})$ & Age \\
\hline MD13-3441BC & Gulf of Cádiz & $35^{\circ} 17.765^{\prime}$ & $06^{\circ} 47.276^{\prime}$ & 532 & 36 & Biogenic sand & $\mathrm{BC}$ & $0-1$ & Recent \\
\hline MD13-3456BC & Alboran Sea (MMF) & $35^{\circ} 26.170^{\prime}$ & $02^{\circ} 30.824^{\prime}$ & 330 & $6 * / 46$ & Biogenic sand & $\mathrm{BC}$ & $0-1$ & Recent \\
\hline MD13-3461BC & Alboran Sea (MMF) & $35^{\circ} 26.528^{\prime}$ & $02^{\circ} 31.065^{\prime}$ & 320 & 3 & Biogenic sand & $\mathrm{BC}$ & $0-1$ & Recent \\
\hline MD13-3465BC & Alboran Sea (MMF) & $35^{\circ} 26.053^{\prime}$ & $02^{\circ} 30.848^{\prime}$ & 346 & 0 & Biogenic sand & $\mathrm{BC}$ & $0-1$ & Recent \\
\hline MD13-3468BC & Alboran Sea (MMF) & $35^{\circ} 25.915^{\prime}$ & $02^{\circ} 30.877^{\prime}$ & 474 & 0 & Biogenic sand & $\mathrm{BC}$ & $0-1$ & Recent \\
\hline MD13-3471BC & Alboran Sea (Cabliers) & $35^{\circ} 47.750^{\prime}$ & $02^{\circ} 15.152^{\prime}$ & 314 & 2 & Biogenic sand & $\mathrm{BC}$ & $0-1$ & Recent \\
\hline TTR17-399G & Alboran Sea (MMF) & $35^{\circ} 20.904^{\prime}$ & $02^{\circ} 32.178^{\prime}$ & 258 & 4 & Biogenic sand & $\mathrm{GC}$ & 40 & Sub-recent \\
\hline TTR17-396G & Alboran Sea (MMF) & $35^{\circ} 20.421^{\prime}$ & $02^{\circ} 31.077^{\prime}$ & 300 & 6 & Biogenic sand & GC & 60 & Sub-recent \\
\hline TTR17-396G & Alboran Sea (MMF) & $35^{\circ} 20.421^{\prime}$ & $02^{\circ} 31.077^{\prime}$ & 300 & 5 & Biogenic sand & $\mathrm{GC}$ & 100 & Sub-recent \\
\hline TTR17-396G & Alboran Sea (MMF) & $35^{\circ} 20.421^{\prime}$ & $02^{\circ} 31.077^{\prime}$ & 300 & 2 & Biogenic sand & GC & 120 & Sub-recent \\
\hline TTR17-396G & Alboran Sea (MMF) & $35^{\circ} 20.421^{\prime}$ & $02^{\circ} 31.077^{\prime}$ & 300 & 4 & Biogenic sand & $\mathrm{GC}$ & 160 & Sub-recent \\
\hline
\end{tabular}

* = living specimens (stained).

(WAG; La Violette, 1986). The MAW is characterized by relatively lower salinities $(<36.5)$ at its entrance into the Alboran Sea and becomes gradually saltier with residence time and mixing with Mediterranean water (Font et al., 1998). The intermediate water mass is composed of Levantine Intermediate Water (LIW), originally generated in the eastern Mediterranean Sea and flowing towards the west below the MAW at a depth interval between ca. 220$1100 \mathrm{~m}$ (La Violette, 1986). The LIW is characterized by temperatures of $\sim 13.1-13.2^{\circ} \mathrm{C}$ and salinities of $\sim 38.5$ (Millot et al., 2006, and references therein). The Western Mediterranean Deep-Water (WMDW) fills the lowest part of the Alboran Basin and represents, together with the LIW, the main source of Mediterranean Outflow Water (MOW) flowing towards the Rockall Channel (Iorga \& Lozier, 1999). Deep-water formation occurs in the Gulf of Lion and is a tributary of the regional circulation pattern, the initial density of the MAW and the LIW and wind strength (Cacho et al., 2000). The Western Mediterranean Deep Water has a temperature of $\sim 12.8-12.9^{\circ} \mathrm{C}$ and salinity of $\sim 38.42-38.45$ in the western Mediterranean sub-basins (van Haren \& Millot, 2004).

Although the Mediterranean Sea is usually considered to be oligotrophic, the Alboran Sea can be regarded as an exception with primary productivity of about $215-250 \mathrm{~g} \mathrm{C}$ $\mathrm{m}^{-2} \mathrm{yr}^{-1}$ (Antoine et al., 1995; Bosc et al., 2004). In particular, two high productivity centers have been recognized in the Alboran Sea, the Almeria-Oran Front system in the eastern part of the Alboran and an upwelling system off Malaga (Vergnaud-Grazzini \& Pierre, 1991).

\section{Geographic Distribution of the Genus SCHACKOINELLA}

The genus Schackoinella Weinhandl, 1958 is poorly known and rarely reported in the literature. Because of its uncommon wall texture, this genus has been placed in different superfamilies (e.g., Orbitoidoidea, Globigerinoidea, Discorboidea) and in different families (e.g., Hantkeninidae, Glabratellidae, Discorbidae). As originally described, this genus includes forms characterized by spines on the spiral side. However, specimens showing this character have also been placed in genera such as Rosalina d'Orbigny, 1826, Glabratella Dorreen, 1948, and
Conorbella Hofker, 1951. Figure 1B displays the geographic distribution of Schackoinella spp. (and morphologically similar forms) and includes their ecological and environmental preferences, if available (Table 2).

\section{MATERIALS AND METHODS}

This study was performed on samples from two gravity cores (GCs) recovered during the cruise TTR-17 in 2008, and on six box cores (BCs, 50 x $50 \mathrm{~cm}$; Fig. 2, Table 1) recovered during the Eurofleets MD194 cruise in June 2013. One of these BCs was collected in the Gulf of Cádiz and five in the eastern Alboran Sea (Fig. 1A, Table 1). Three surface-sample replicates were collected from each BC. Additionally, three to four sub-cores $(10 \mathrm{~cm}$ in diameter, up to $1 \mathrm{~m}$ long) were collected for each BC. The protocol for micropaleontological studies of Schönfeld et al. (2012) was applied to surface sediments. After description, the surface samples were collected with a graduated cylinder $(8 \mathrm{~cm}$ in diameter and $1 \mathrm{~cm}$ high; total volume $=50 \mathrm{~cm}^{3}$ ), preserved in plastic containers with an ethanol-rose Bengal solution (2 $\mathrm{g} / \mathrm{L}$ ), and stored at $4^{\circ} \mathrm{C}$ for at least 3 weeks. Samples were then washed through a $63 \mu \mathrm{m}$ mesh sieve and live (stained) and fossil (not stained) benthic foraminifera were analyzed from this fraction. The split size was defined by a target value of 300 specimens. Splits were picked and counted entirely. The gravity cores (Fig. 3) were sampled at $20 \mathrm{~cm}$ intervals for geochemical and micropaleontological investigations. Samples were processed following standard procedures for foraminiferal preparation. Approximately $10 \mathrm{~g}$ of dry bulk sediment sample was washed through three sieves $(63,125$ and $250 \mu \mathrm{m})$ and at least 200 specimens per fraction were counted and glued on plummer cells for archiving. All samples were quantitatively investigated for their benthic foraminiferal content. In the samples containing the new species, all residues were systematically investigated to collect a maximum of specimens.

Scanning electron microscope (SEM) images were taken with a FEI Sirion XL30 FEG SEM and all specimens were coated with a $20 \mathrm{~nm}$ gold layer. Images for the holotype were performed using a SEM Phenom ProX. The holotype was not coated to avoid damaging the specimen. Figure 1 shows the location of the stations/cores where Schackoinella 


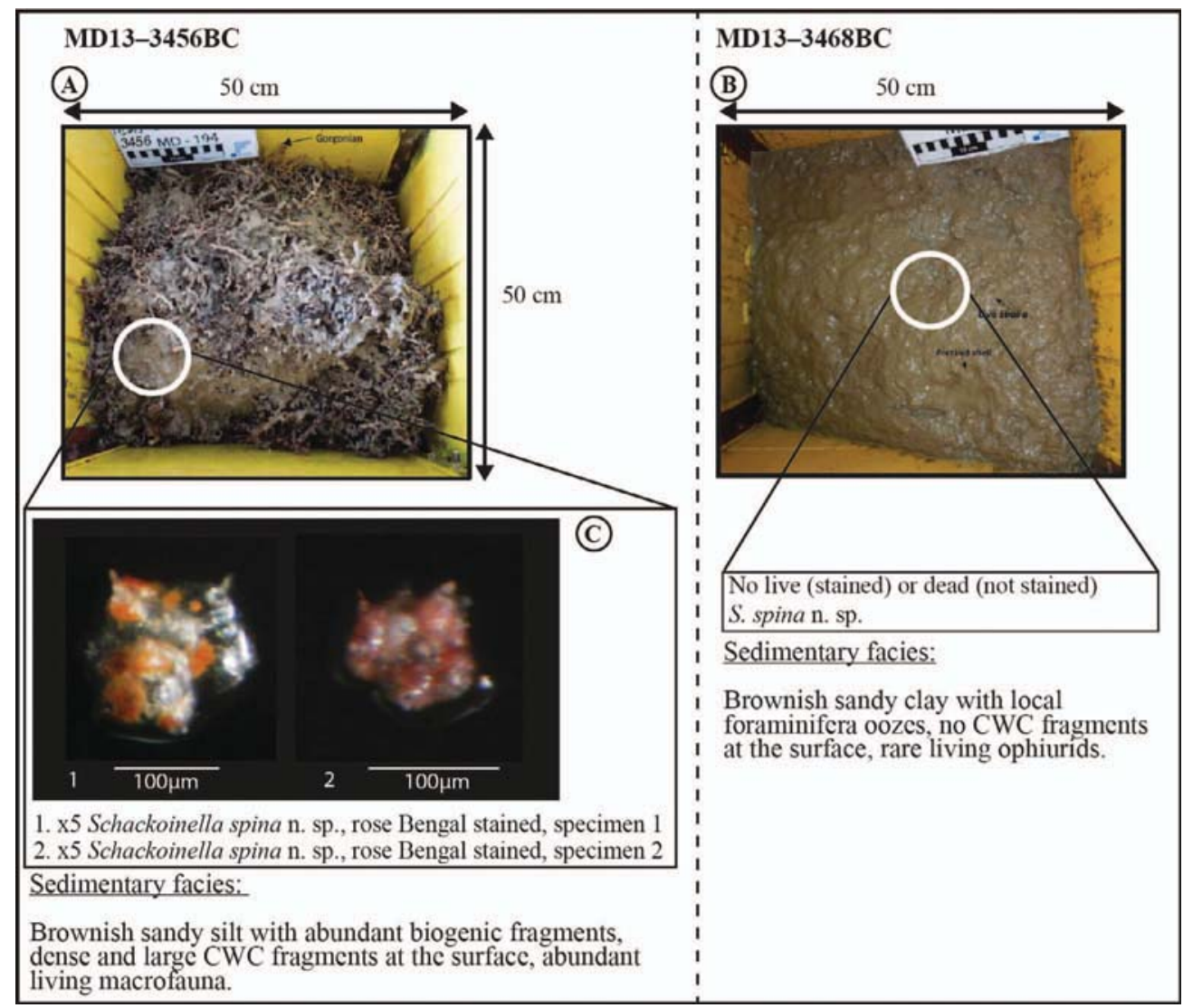

Figure 2. A, B Sedimentary characteristics of the surface of box cores MD13-3456BC and MD13-3468BC; C Picture showing two rose Bengal stained specimens of Schackoinella spina Stalder \& Spezzaferri n. sp.

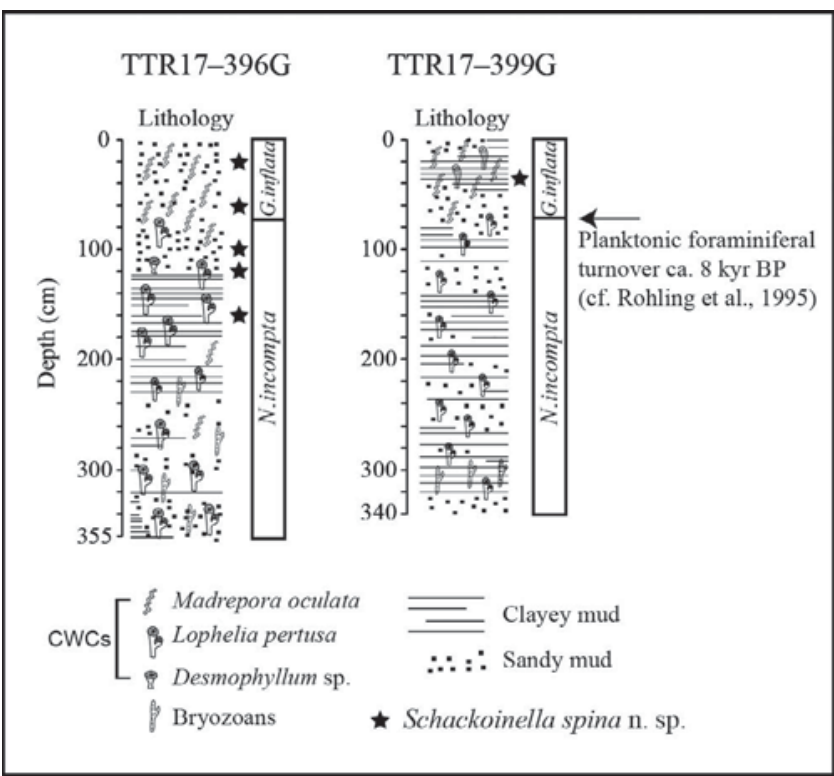

FIGURE 3. Lithology and log of sediment cores TTR17-396G and TTR17-399G including the distribution of the main macrofaunal components. The figure displays the distribution of the dominant planktonic foraminiferal assemblages and the samples where S. spina Stalder \& Spezzaferri n. sp. were found. spina n. sp. occurred and Table 1 summarizes the number of live (stained) and fossil specimens counted for each station.

To document the size range of the new species, we applied basic morphometric analyses on a selection of specimens $(n=37)$ with relatively well-preserved chambers. From these 37 specimens, 3 were rose Bengal stained (i.e., live). As the spines of most specimens were damaged, possibly during sample preparation, we measured the maximum (length) and the minimum (width) diameters of the tests (Fig. 4). The 37 specimens were first documented with SEM images from the dorsal view and the morphometric parameters were then measured with the oOlympus "measureIT" software.

\section{Sedimentology}

The sediments from the surface of the BCs and the sediments from the GCs in which $S$. spina were found were all characterized by CWC fragments up to $20 \mathrm{~cm}$ in diameter (Figs. 2, 3) and by abundant biogenic components such as bryozoans, gastropods, bivalves, serpulids, and planktonic and benthic foraminifera. The surface samples of box cores MD13-3465BC and MD13-3468BC (Fig. 2, Table 1) recovered from the same study area did not contain any $S$. spina and were both characterized by fine grained sediment with few or no CWC fragments (Van Rooij et al., 2013). 


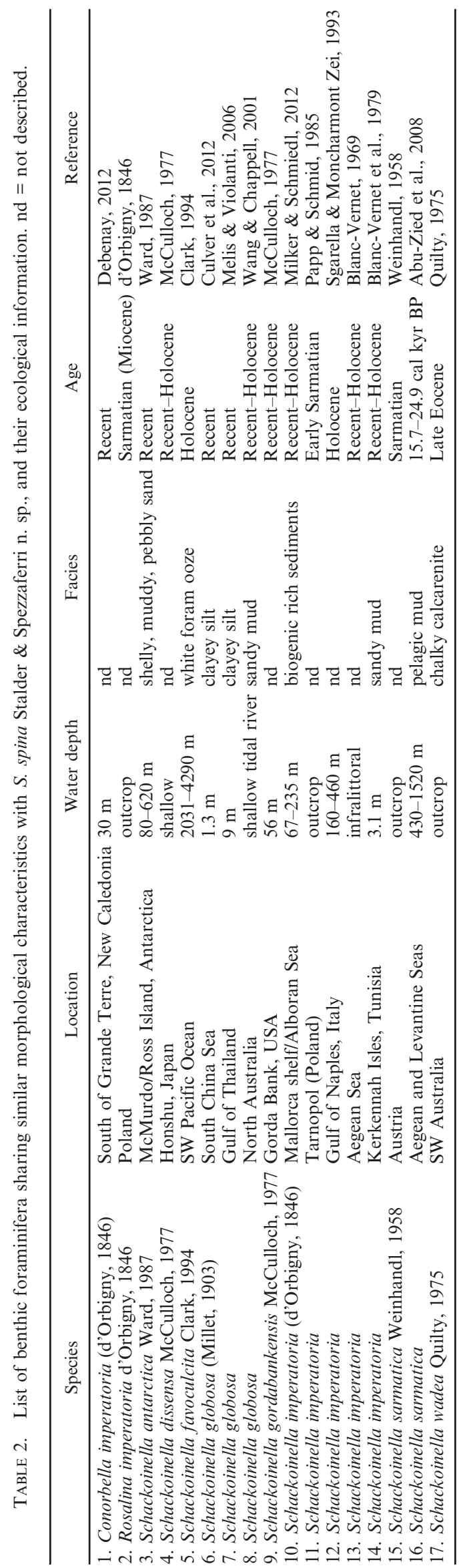

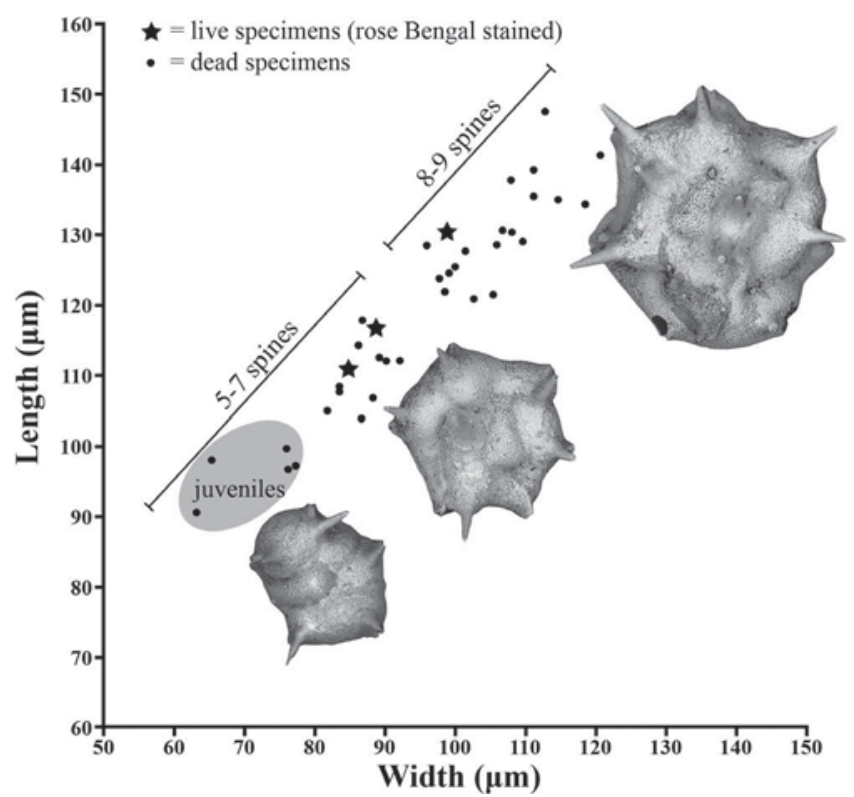

FIGURE 4. Length and width data for 37 specimens of Schackoinella spina Stalder \& Spezzaferri n. sp.

\section{SYSTEMATICS}

Order FORAMINIFERIDA d'Orbigny, 1826 Superfamily GLABRATELLOIDEA

Loeblich \& Tappan, 1964

Family GLABRATELLIDAE Loeblich \& Tappan, 1964

Genus Schackoinella Weinhandl, 1958

Type species Schackoinella sarmatica Weinhandl, 1958

Schackoinella spina Stalder \& Spezzaferri n. sp.

Figure 5.1-4

Description. This species has a low to medium-high trochospire consisting of 2 to $2 \frac{1}{2}$ whorls. The first chambers on the spiral side are rectangular and become triangular in the last whorl. On the umbilical side the chambers are subtriangular and inflated, with radial U-shaped incisions (grooves) that extend from the aperture to the base of the chambers in correspondence with the spines. The grooves coincide with the sutures, are particularly well-developed (Fig. 5.1c) and reach the periphery of the test. They are bordered by a thick inflated lip (Fig. 5.3c). The chambers increase rapidly in size as added, with up to five in the last whorl. Well-developed spines arise from the midpoint of each chamber, one per chamber, with the exception of the second chamber after the proloculus, which has two spines. Intact spines are generally up to $50 \mu \mathrm{m}$ long with a relatively massive base well demarcated from the chamber. The peripheral margin is rounded and the test outline is slightly lobate. Sutures are depressed and straight on the umbilical side. Fine radial striae (one per chamber) are visible at the margin of the aperture and disappear gradually towards the periphery of the test. The umbilicus is widely open, with a centered large and circular aperture connecting to all chambers. The wall texture is smooth to slightly reticulate. One of the most characteristic features of this new species is that the proloculus is more coarsely perforate than the other chambers (Fig. 5.2b).

Etymology. Named spina because it has long spines in the middle part of each chamber. 


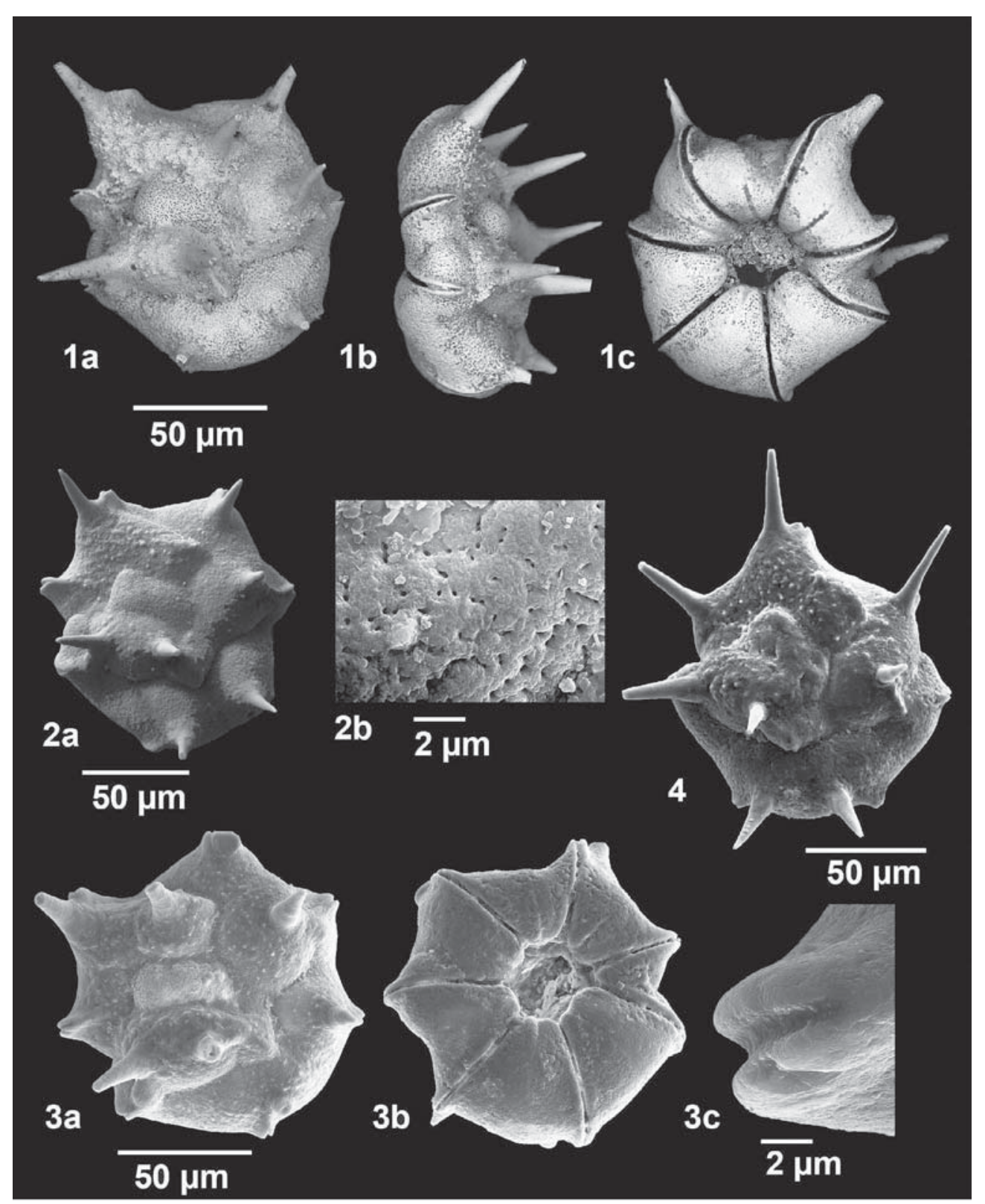

Figure 5. Plate illustrating Schackoinella spina Stalder \& Spezzaferri n. sp. 1a x1150, Holotype MHNF32031, dorsal view, not coated, from MD13-3441BC. 1b x1100, Holotype MHNF32031, side view, not coated, from MD13-3441BC. 1c x1150, Holotype MHNF32031, ventral side, not coated, from MD13-3441BC. 2a x500, Paratype MHNF32032, dorsal view, from MD13-3461BC. 2b x2000, Same paratype MHNF32032, expanded view, from MD13-3461BC. 3a x500, Paratype MHNF32033, dorsal view, from TTR17-396G-160 cm. 3b x500, Same paratype MHNF32033, ventral view, from TTR17-396G-160 cm. 3c x2000, Same paratype MHNF32033, expanded view, from TTR17-396G-160 cm. 4 x500, Paratype MHNF32034, dorsal view, from MD13-3456BC.

Dimension. Average diameter $0.11 \mathrm{~mm}$, range $0.06-0.14$ mm (Fig. 4).

Type Level. Eastern Alboran Sea and Gulf of Cádiz (Table 1). The holotype is from the surface sample of box core MD13-3441BC, recovered at $35^{\circ} 17.765^{\prime} \mathrm{N}$, $06^{\circ} 47.276^{\prime} \mathrm{W}$ at $532 \mathrm{~m}$ water depth. The sedimentary facies consists of cold-water coral fragments and abundant coarse biogenic components in a muddy-sand matrix.

Type Material. A paratype series of three specimens was selected. Other material examined consists of more than 80 specimens. Additional bulk sediment from the same subsamples is stored at the University of Fribourg.
Geographic Distribution. This species has been observed in Holocene sediments from the Alboran Sea. A few live specimens (6) were also found on $\mathrm{BC}$ tops from the same regions. These specimens are stored at the Department of Earth Sciences of the University of Fribourg in plummer cells.

Repository. The holotype MHNF32031 from MD133441 BC and 3 selected paratypes (Fig. 5.2-4) MHNF32032 from MD13-3461BC, MHNF32033 from TTR17-396G-160 and MHNF32034 from MD13-3456BC are on an SEM stub in the collection of the Natural History Museum of Fribourg, Switzerland. Additionally, 44 specimens of the 
new species are stored at the Natural History Museum of Fribourg under the reference number MHNF32035.

Distinguishing Features. Schackoinella spina differs from Murrayinella globosa (Millett, 1903) by having rectangular/ subrectangular to triangular chambers on the spiral side instead of globular, two spines on the second chamber instead of none, a slightly conical spiral side instead of a flat side, and a wide aperture instead of small and indistinct.

This species differs from Conorbella imperatoria (d'Orbigny, 1846) by having radial U-shaped incisions extending from the aperture to the base of the chambers in correspondence with the spines, a rounded peripheral margin instead of subacute, and the second chambers with two spines instead of one. Additionally, $C$. imperatoria has more regular chambers increasing moderately in size as added and separated by backward sutures, characters that are not present in S. spina.

Schackoinella spina differs from Schackoinella sarmatica Weinhandl, 1958 by its rectangular/subrectangular chambers on the spiral side and by the two spines on the second chamber after the proloculus.

Schackoinella spina is different in several aspects from the Schackoinella wadeae described by Quilty (1975) from the Nanarup Limestone Member of the Werillup Formation (Western Australia): the spines of the new species are longer and well demarcated from the chambers. The wall texture of $S$. wadeae is finely perforated, but not reticulated. The aperture of this latter species is narrower and its margin is ornamented with a series of fine striae that are not present in S. spina.

Clark (1994) reported the species Schackoinella favoculcita Clark, 1994 from the deep (2031-4290 m) tropical SW Pacific Ocean. This species differs from $S$. spina by its strongly reticulate dorsal ornament, well-rounded periphery, and nearly circular outline.

McCulloch (1977) described two species from the Pacific Ocean attributed to the genus Schackoinella: S. dissensa McCulloch, 1977 and S. gordabankensis McCulloch, 1977. Schackoinella dissensa shows important similarities to $M$. globosa, with globular chambers and dense hispid wall ornaments characteristic of the genus Murrayinella. This species is different from $S$. spina because of its relatively high trochospiral test, its semiglobose chambers and the granular wall texture. The second species described by McCulloch (1977), $S$. gordabankensis, is larger $(200 \mu \mathrm{m}$ in the maximum diameter of the test) than S. spina; it also has eight chambers in the last whorl, while S. spina has only five. Schackoinella gordabankensis lacks the typical morphological characteristics of $S$. spina, which are the prominent grooves at the periphery of the test, two spines on the second chamber of the test and the coarsely perforate proloculus. Furthermore, the specimen of $S$. gordabankensis, as illustrated in McCulloch (1977), is characterized by ten spines on the dorsal side. None of our $S$. spina specimens has more than nine spines (Fig. 4).

The new species shows certain morphological similarities with Schackoinella antarctica Ward, 1987, found in the McMurdo Sound (Ross Sea) and on outcrops from the Ross Island (Fig. 1B). Both have a slightly reticulate wall texture, the apertures of all chambers are arranged to form an open and centered umbilicus, and both species have radial grooves or striae on the umbilical side. However, $S$. spina clearly differs from $S$. antarctica by its rectangular to subrectangular chambers on the spiral side and by the total number of chambers, which are up to five in the last whorl for $S$. spina and four for $S$. antarctica. Furthermore, $S$. spina usually has one long spine per chamber except for the second chamber, which is characterized by the presence of two long spines instead of numerous shorter spines all over the test, as in $S$. antarctica. One of the most characteristic features of this new species is the differentially coarser, perforate proloculus, which is smooth in S. antarctica. The sutures of $S$. spina are less depressed than those of $S$. antarctica and the grooves are more marked, especially at the periphery of the test.

\section{DISCUSSION}

The new species described has been attributed to the genus Schackoinella (type species Schackoinella sarmatica Weinhandl, 1958) because it possesses all the typical characteristics of the genus (see also Loeblich \& Tappan, 1987), such as a trochospiral test, consisting of very few whorls, spines in the midpoint of each chamber, and a smooth to reticulate wall texture. Presently accepted as belonging to the Schackoinella genus are S. sarmatica Weinhandl, 1958, S. wadeae Quilty, 1975, S. dissensa McCulloch, 1977, S. gordabankensis McCulloch, 1977, S. antarctica Ward, 1987, and S. favoculcita Clark, 1994.

To provide a global overview of ecological preferences and distribution of different species that have been attributed to the genus Schackoinella in the literature, we here discuss similarities and differences with species displaying evident morphological characters of the genus Schackoinella. These species are C. imperatoria (d'Orbigny, 1846), which Quilty (1975) and Ward (1987) both agree should be referred to the genus Schackoinella, and $M$. globosa (Millett, 1903; Table 2).

\section{Distribution AND ECOLOGY OF SCHACKOINELLA SPINA}

The relatively low number of samples, which were recovered during the mentioned cruises and available for micropaleontology, makes it problematic to clearly attribute the new species to the Eastern Alboran Sea-Gulf of Cádiz seaway or clearly associate it to CWC ecosystems. This species was not reported in previous studies from this region (Table 3; e.g., Margreth et al., 2011) and was not previously observed associated with other CWC ecosystems along the northern European margin, such as the Norwegian Shelf, the Porcupine Seabight and Rockall Trough (Fig. 1A).

However, this study shows that the new species is, indeed, present in the eastern Alboran Sea and in the Gulf of Cádiz (Table 1) where CWC ecosystems occur. Its presence may have been overlooked due to its small size (Fig. 4). Milker \& Schmiedl (2012) reported the occurrence of the larger species, Conorbella imperatoria, from the Alboran Sea and the Mallorca Shelf in their $125 \mu \mathrm{m}$ sieve fraction (Tables 2, 3). We found our specimens of $S$. spina (Fig. 4) exclusively in the smallest sieve fraction $(63 \mu \mathrm{m})$, thus providing additional evidence that these two species found in the Alboran Sea are clearly different. 
TABLE 3. List of detailed studies on benthic foraminifera assemblages from the Alboran Sea. The list provides the sieve size used for these studies. $\mathrm{WAB}=$ Western Alboran Basin; $\mathrm{BC}=$ Box-core; $\mathrm{GC}=$ Gravity-core

\begin{tabular}{|c|c|c|c|c|c|}
\hline Reference & Fraction $(\mu \mathrm{m})$ & Area & Water depth (m) & Gear & Age \\
\hline Auffret et al., 1974 & $>160$ & Alboran & $350-2640$ & BC (surface) & Recent \\
\hline Cita \& Zocchi, 1978 & $>63$ & WAB & $878-1371$ & GC (surface) & Recent \\
\hline Caralp, 1988 & $>250$ & WAB & $795-1375$ & $\mathrm{GC}$ & Pleistocene-Holocene \\
\hline Vergnaud-Grazzini et al., 1989 & $>250$ & WAB & 795 & $\mathrm{GC}$ & Pleistocene-Holocene \\
\hline El Khanchoufi et al., 2000 & $>40$ (qualitative) & WAB & 750 & GC & Holocene \\
\hline Margreth et al., 2011 & $>63$ & WAB & $370-410$ & $\mathrm{GC}$ & Holocene \\
\hline Milker \& Schmiedl, 2012 & $>125$ & Alboran Platform & $31-161$ & BC (surface) & Recent \\
\hline
\end{tabular}

Furthermore, C. imperatoria has not been found on CWC settings so far.

The higher abundance of dead (46) and living tests (6) of $S$. spina in surface samples (MD13-3456BC) from the Alboran Sea and from the Gulf of Cádiz (36 dead) compared to the lower abundances at other stations (1 dead) may be interpreted as due to different local environmental conditions. In particular, since $S$. spina is absent in typical finegrained pelagic facies that are also devoid of cold-water coral fragments (e.g., box core MD13-3468BC; Fig. 2), we suggest that hard-bottom substratum represented by coral framework and the sediment grain size may be the limiting factors for the distribution of this new species. Schönfeld (2011) and Spezzaferri et al. (2013) have demonstrated that, in CWC ecosystems, epibenthic foraminifera such as Cibicides lobatulus (Walker \& Jacob), Cibicides refulgens de Montfort, and Discanomalina coronata (Parker \& Jones) colonize preferentially elevated hard substrates like coral branches or other biogenic fragments where bottom currents are stronger and the availability of food particles is higher. The preferred, permanently attached, living strategy of species with morphological affinities [e.g., C. imperatoria (d'Orbigny, 1846)] has already been described by Tóth \& Görög (2008) and could represent a major characteristic of the living strategy also for the genus Schackoinella. Regarding the few specimens and sampling sites, it is, however, not possible to clearly define the ecological preferences that control the distribution of $S$. spina.

Specimens of $S$. spina were found at water depths ranging from 258-532 m. Schackoinella antarctica was found at a corresponding depth in the Ross Sea (Ward, 1987). Schackoinella favoculcita was recovered from the deep Pacific Ocean in water depths from 2031-4290 m (Clark, 1994). McCulloch (1977) found the species $S$. dissensa and $S$. gordabankensis in shallow waters not exceeding $56 \mathrm{~m}$ water depth. Milker \& Schmiedl (2012) reported $C$. imperatoria from the Mallorca shelf between 67-235 $\mathrm{m}$ and the species $M$. globosa (= S. globosa) was reported from shallow (1.3-9 m) sites in the South China Sea (Culver et al., 2012), the Gulf of Thailand (Melis \& Violanti, 2006), and western Australia (Wang \& Chappell, 2001), demonstrating that these species have diverse habitats ranging from tidal flats down to deep-sea environments. In particular, the depth range of $S$. spina corresponds to the depth of occurrence of CWC in the Alboran-Cádiz gateway, suggesting a possible causal link between their occurrences.

Finally, this study reveals that the occurrence of this species is constrained to the upper part of the investigated cores (Fig. 3, Table 1). Based on the planktonic foraminiferal turnover reported in the Alboran Sea at ca. $8 \mathrm{ka}$ BP by Rohling et al. (1995), from an interval dominated by Neogloboquadrina incompta (Cifelli) to an interval dominated by Globorotalia inflata (d'Orbigny), we infer that $S$. spina has been present in the eastern Alboran Sea at least since the early Holocene.

\section{CONCLUSIONS}

We describe here Schackoinella spina, a new species occurring in sediment surface and core samples from the eastern Alboran Sea and the Gulf of Cádiz. Live (stained) specimens from surface samples indicate that this new species is extant in the eastern Alboran Sea. Fossil specimens from gravity cores indicate that $S$. spina has been present in the eastern Alboran since at least the early Holocene. No specimens have been found in older sediments (core) or from surface sediments characterized by fine-grained sediments, indicating preference for hard substrata represented by the cold-water coral framework and coarser grain-size.

\section{ACKNOWLEDGMENTS}

We thank the captains and crews of $\mathrm{R} / \mathrm{V}$ Professor Logatchev and R/V Marion Dufresne for their valuable help onboard. The authors also thank the reviewers, Dr. Gerhard Schmiedl and Dr. Fabrizio Frontalini, for their help and their useful comments on the manuscript. The MD194 EUROFLEETS cruise was carried out under Grant Agreement $n^{\circ} 228344$, with full and duly acknowledged support of IPEV. We are especially grateful to Agostina Vertino from the University of Milano-Bicocca for the descriptions of the box cores. Many thanks to the Swiss National Foundation projects 200020_131829 and 200020_153125, which provided financial support. The lead author (CS) warmly acknowledges the Cushman Foundation for Foraminiferal Research for the Johanna M Resig Fellowship 2014. This research frames also under the ESF COCARDE European Research Network.

\section{REFERENCES}

Abu-Zied, R. H., Rohling, E. J., Jorissen, F. J., Fontanier, C., Casford, J. S. L., and Cooke, S., 2008, Benthic foraminiferal response to changes in bottom-water oxygenation and organic carbon flux in the eastern Mediterranean during LGM to recent times: Marine Micropaleontology, v. 67, p. 46-68. 
Antoine, D., Morel, A., and Andre, J., 1995, Algal pigment distribution and primary production in the eastern Mediterranean as derived from Coastal Zone Color Scanner observations: Journal of Geophysical Research, v. 100, p. 16193-16209.

Auffret, G.-A., Pastouret, L., Chamley, H., and Lanoix, F., 1974, Influence of the prevailing current regime on sedimentation in the Alboran Sea: Deep-Sea Research, v. 21, p. 839-849.

Blanc-Vernet, L., 1969, Contribution à l'étude des foraminifères de Méditerranée: Recueil des Travaux de la Station Marine d'Endoume, v. 48, p. 1-281.

Blanc-Vernet, L., Clairefond, P., and Orsolini, P., 1979, Les foraminifères in Burollet, P. F. et al. (eds.), La mer pélagienne, étude sédimentologique et écologique du Plateau tunisien et du Golfe de Gabès:. Géologie Méditerranéenne, Marseille v. 6, p. 171-209.

Bosc, E., Bricaud, A., and Antoine, D., 2004, Seasonal and interannual variability in algal biomass and primary production in the Mediterranean Sea, as derived from 4 years of SeaWiFS observations: Global Biogeochemical Cycles, v. 18, GB1005, doi:10.1029/2003GB002034.

Cacho, I., Grimalt, J. O., Sierro, F. J., Shackleton, N. J., and Canals, M., 2000, Evidence for enhanced Mediterranean thermohaline circulation during rapid climatic coolings: Earth Planetary Science Letters, v. 183 , p. 417-429.

Caralp, M., 1988, Late glacial to recent deep-sea benthic foraminifera from the northeastern Atlantic (Cadiz Gulf) and western Mediterranean (Alboran Sea): paleoceanographic results: Marine Micropaleontology, v. 13, p. 265-289.

Cita, M. B., and Zocchi, M., 1978, Distribution patterns of benthic foraminifera on the floor of the Mediterranean Sea: Oceanologica Acta, v. 1, p. $445-462$

Clark, F. E., 1994, New species and a new genus of Neogene benthic foraminifera from the Southwest Pacific Ocean: Journal of Foraminiferal Research, v. 24, p. 110-122.

Comas, M. C., and Pinheiro, L. M., 2008, Discovery of Carbonate Mounds in the Alboran Sea: The Melilla Mound Field: General Proceedings of the 33rd International Geological Congress, Oslo, Norway, http://iugs.org/33igc/downloads/33IGC_GenPro_web. pdf (Accessed 13 July 2015)

Comas, M. C., Platt, J. P., Soto, J. I., and Watts, A. B., 1999 Proceedings of ODP, Scientific Results, 161: College Station, TX (Ocean Drilling Program), p. 555-579.

Comas, M. C., Pinheiro, L. M., Ivanov, M., and TTR-17 Leg 1 Scientific Party, 2009 Deep-Water Coral Mounds in the Alboran Sea: The Melilla Mound Field Revisited, in Geo-Marine Research on the Mediterranean and European-Atlantic Margins: International Conference and TTR-17 Post-Cruise Meeting of the Training-through-Research Programme: Granada, Spain, 2-5 February 2009, IOC Workshop Report, v. 220, p. 8-9.

Culver, S. J., Mallinson, D. J., Corbett, D. R., Leorri, E., Rouf, A. A., Shazili, N. A. M., Yaacob, R., Whittaker, J. E., Buzas, M. A. and Parham, P. R., 2012, Distribution of Foraminifera in the Setiu Estuary and Lagoon, Terengganu, Malaysia: Journal of Foraminiferal Research, v. 42, p. 109-133.

Davies, A. J., Duineveld, G., Lavaleye, M., Bergman, M., van Haren, H., and Roberts, J. M., 2009, Downwelling and deep-water bottom currents as food supply mechanisms to the cold-water coral Lophelia pertusa (Scleractinia) at the Mingulay Reef Complex: Limnology and Oceanography, v. 54, p. 620-629.

Debenay, J.-P., 2012, A guide to 1,000 Foraminifera from Southwestern Pacific New Caledonia: IRD Editions, Institut de recherche pour le développement, Marseille, $378 \mathrm{p}$

d'Orbigny, A. D., 1826, Tableau Méthodique de la Classe des Cépahlopodes: Annales des Sciences Naturelles, Paris, Séries 1, v. 7, p. $245-314$

d'Orbigny, A. D., 1846, Foraminifères fossiles du Bassin Tertiaire de Vienne (Autriche): Paris, Gide et Compe, $312 \mathrm{p}$

Dorreen, J. M., 1948, A foraminiferal fauna from the Kaiatan Stage (Upper Eocene) of New Zealand: Journal of Paleontology, v. 22, p. 271-300.

Duineveld, G. C. A., Lavaleye, M. S. S., and Berghuis, E. M., 2004, Particle flux and food supply to a seamount cold-water coral community (Galicia Bank, NW Spain): Marine Ecology Progress Series, v. 277 , p. $13-23$.
Duineveld, G. C. A., Lavaleye, M. S. S., Bergman, M. J. N., De Stigter, H. C., and Mienis, F., 2007, Trophic structure of a cold-water coral mound community (Rockall Bank, NE Atlantic) in relation to the near-bottom particle supply and current regime: Bulletin Marine Science, v. 81, p. 449-467.

Dullo, W.-C., Flögel, S., and Rüggeberg, A., 2008, Cold-water coral growth in relation to the hydrography of the Celtic and Nordic European continental margin: Marine Ecology Progress Series, v. 371, p. $165-176$.

El Khanchoufi, A., Civis, J., and El Moumni, B., 2000, The foraminiferal assemblages of the Moroccan side of the Alboran Sea as a record of climatic changes in the Upper Pleistocene-Holocene: Revista de la Sociedad Geológica de España, v. 13, p. 157-163.

Fink, H. G., Wienberg, C., Hebbeln, D., McGregor, H. V., Schmiedl, G., Taviani, M., and Freiwald, A., 2012, Oxygen control on Holocene cold-water coral development in the eastern Mediterranean Sea: Deep Sea Research Part I: Oceanographic Research Papers, v. 62, p. 89-96.

Fink, H. G., Wienberg, C., De Pol-Holz, R., Wintersteller, P., and Hebbeln, D., 2013, Cold-water coral growth in the Alboran Sea related to high productivity during the Late Pleistocene and Holocene: Marine Geology, v. 339, p. 71-82.

Font, J., Millot, C., Salas, J., Julià, A., and Chic, O., 1998, The drift of Modified Atlantic Water from the Alboran Sea to the eastern Mediterranean: Scientia Marina, v. 62, p. 211-216.

Freiwald, A., Fossa, J. H., Grehan, A., Koslow, T., and Roberts, J. M., 2004, Cold-water coral reefs: UNEP-WCMC, Cambridge.

Heburn, G. W., and La Violette, P. E., 1990, Variations in the structure of the Anticyclonic Gyres found in the Alboran Sea: Journal of Geophysical Research, v. 95, p. 1599-1613.

Henriet, J. P., Hamoumi, N., Da Silva, A. C., Foubert, A., Lauridsen, B. W., Rüggeberg, A., and Van Rooij, D., 2014, Carbonate mounds: From paradox to World Heritage: Marine Geology, v. 352, p. $89-110$

Hofker, J., 1951, The foraminifera of the Siboga expedition. Part III: Siboga-Expeditie, Monographie IVa, E. J. Brill, Leiden, 513 p.

Hovland, M., Croker, P. F., and Martin, M., 1994, Fault-associated seabed mounds (carbonate knolls?) off western Ireland and north-west Australia: Marine and Petroleum Geology, v. 11, p. $232-246$.

Iorga, M., and Lozier, M. S., 1999, Signatures of the Mediterranean outflow from a North Atlantic climatology 1. Salinity and density fields: Journal of Geophysical Research, v. 104, p. 25985-26009.

Joseph, N., López Correa, M., Schönfeld, J., Rüggeberg, A., and Freiwald, A., 2013, Sub-arctic Holocene climatic and oceanographic variability in Stjernsund, northern Norway: evidence from benthic foraminifera and stable isotopes: Boreas, v. 42, p. $511-531$.

Kiriakoulakis, K., Bett, B. J., White, M., and Wolff, G. A., 2004 Organic biogeochemistry of the Darwin Mounds, a deep-water coral ecosystem, of the NE Atlantic: Deep-Sea Research Part I, Oceanographic Research Papers, v. 51, p. 1937-1954.

Loeblich, A. R., and Tappan, H., 1964, Part C. Protista 2. Chiefly "Thecamoebians" and Foraminiferida, in Moore, R. C., (ed.), Treatise on Invertebrate Paleontology: The Geological Society of America and the University of Kansas, Lawrence Kansas, 900 p.

Loeblich, A. R., and Tappan, H., 1987, Foraminiferal Genera and their Classification: Van Nostrand Reinhold, New York, $970 \mathrm{p}$

Margreth, S., Rüggeberg, A., and Spezzaferri, S., 2009, Benthic foraminifera as proxies for cold-water coral reef ecosystems along the Irish Margin: Deep-Sea Research Part I, Oceanographic Research Papers, v. 56, p. 2216-2234.

Margreth, S., Gennari, G., Rüggeberg., Comas, M. C., Pinheiro, L., and Spezzaferri, S., 2011, Growth and demise of cold-water coral ecosystems on mud volcanoes in the West Alboran Sea: messages from the planktonic and benthic foraminifera: Marine Geology, v. 282 , p. $26-39$

McCulloch, I., 1977, Qualitative Observations on Recent Foraminiferal Tests with Emphasis on the Eastern Pacific: University of Southern California Press, Los Angeles, 1078 p.

Melis, R., and Violanti, D., 2006, Foraminiferal biodiversity and Holocene evolution of the Phetchaburi coastal area (Thailand Gulf): Marine Micropaleontology, v. 61, p. 94-115. 
Milker, Y., and Schmiedl, G., 2012, A taxonomic guide to modern benthic shelf foraminifera of the western Mediterranean Sea: Palaeontologia Electronica, v. 15, p. 1-134.

Millett, F. W., 1903, Report on the Recent foraminifera of the Malay Archipelago collected by Mr. A. Durrand: Royal Microscopical Society, p. 684-704

Millot, C., Candela, J., Fuda, J. L., and Tber, Y., 2006, Large warming and salinification of the Mediterranean outflow due to changes in its composition: Deep-Sea Research Part I, Oceanographic Research Papers, v. 53, p. 656-666.

Papp, A., and Schmid, M. E., 1985, The Fossil Foraminifera of the Tertiary Basin of Vienna: Revision of the monograph by Alcide d'Orbigny (1846): Abhandlungen der Geologischen Bundesanstalt, v. 37, p. 1-311.

Parrilla, G., Kinder, T. H., and Preller, R. H., 1986, Deep and intermediate Mediterranean water in the Western Alboran Sea: Deep-Sea Research Part I, Oceanographic Research Papers, v. 33, p. 55-88.

Quilty, P. G., 1975, A new species of Schackoinella from the Eocene of western Australia with comments on Glabratellidae: Journal of Foraminiferal Research, v. 5, p. 326-333.

Roberts, J. M., Wheeler, A. J., and Freiwald, A., 2006, Reefs of the deep: the biology and geology of cold-water coral ecosystems: Science, v. 312 , p. 543-547.

Rohling, E. J., Den Dulk, M., Pujol, C., and Vergnaud-Grazzini, C., 1995, Abrupt hydrographic change in the Alboran Sea (western Mediterranean) around 8000 yrs BP: Deep-Sea Research Part I, Oceanographic Research Papers, v. 42, p. 1609-1619.

Rüggeberg, A., Dullo, C., and Dorschel, B., 2007, Environmental changes and growth history of Propeller Mound, Porcupine Seabight: Evidence from benthic foraminiferal assemblages: International Journal of Earth Sciences, v. 96, p. 57-72.

Schönfeld, J., Dullo, W. C., Pfannkuche, O., Freiwald, A., Rüggeberg, A., Schmidt, S., and Weston, J., 2011, Recent benthic foraminiferal assemblages from cold-water coral mounds in the Porcupine Seabight: Facies, v. 57, p. 187-213.

Schönfeld, J., Jorissen, F., Korsun, S., Alve, E., Geslin, E., Spezzaferri, S., and members of the FOBIMO Working Group, 2012, The FOBIMO (FOraminiferal BIo-Monitoring) initiative - towards a formalised protocol for benthic foraminiferal monitoring studies: Marine Micropaleontology, v. 94, p. 1-13.

Sgarrella, F., and Moncharmont Zei, M., 1993, Benthic foraminifera of the Gulf of Naples (Italy): systematics and auto ecology: Bollettino della Societa' Paleontologica Italiana, v. 32, p. 145-264.

Smeulders, G. G. B., Koho, K. A., de Stigter, H. C., Mienis, F., de Haas, H., and van Weering, T. C. E., 2014, Cold-water coral habitats of Rockall and Porcupine Bank, NE Atlantic Ocean: Sedimentary facies and benthic foraminiferal assemblages: Deep-Sea Research Part II, Topical Studies in Oceanography, v. 99, p. 270-285.

Spezzaferri, S., Rüggeberg, A., Stalder, C., and Margreth, S., 2013, Benthic foraminifera from Norwegian cold-water coral reefs: Journal of Foraminiferal Research, v. 43, p. 21-39.

Spezzaferri, S., Rüggeberg, A., and Stalder, C., (eds.), in press, Atlas of benthic foraminifera from cold-water coral reefs. Cushman Foundation for Foraminiferal Research, Special Publication No. 44, 367 p.

Stalder, C., Spezzaferri, S., Rüggeberg, A., Pirkenseer, C., and Gennari, G., 2014, Late Weichselian deglaciation and early Holocene development of a cold-water coral reef along the Lopphavet shelf (Northern Norway) recorded by benthic foraminifera and ostracoda: Deep-Sea Research Part II: Topical Studies in Oceanography, v. 99, p. 249-269.

Tóth, E., and Görög, Á., 2008, Sarmatian foraminifera fauna from Budapest (Hungary): Hantkeniana 6, 125th Anniversary of the Department of Palaeontology at Budapest University, A Jubilee Volume, p. 187-217.

van Haren, H., and Millot, C., 2004, Rectilinear and circular inertial motions in the Western Mediterranean Sea: Deep-Sea Research Part I: Oceanographic Research Papers, v. 51, p. 1441-1455.

Van Rensbergen, P., Depreiter, D., Pannemans, B., Moerkerke, G., van Rooij, D., Marsset, B., Akhmanov, G., Blinova, V., Ivanov, M., Rachidi, M., Magalhaes, V., Pinheiro, L., Cunha, M., and Henriet, J. P., 2005, The Arraiche mud volcano field at the Moroccan Atlantic slope, Gulf of Cadiz: Marine Geology, v. 219, p. 1-17.

Van Rooij, D., Blamart, D., De Mol, L., Mienis, F., Pirlet, H. Wehrmann, L. M., Barbieri, R., Maignien, L., Templer, S. P., de Haas, H., Hebbeln, D., Frank, N., Larmagnat, S., Stadnitskaia, A., Stivaletta, N., van Weering, T., Zhang, Y., Hamoumi, N., Cnudde, V., Duyck, P., Henriet, J.-P., and the The MiCROSYSTEMS MD 169 shipboard party, 2011, Cold-water coral mounds on the Pen Duick Escarpment, Gulf of Cadiz: the MiCROSYSTEMS project approach: Marine Geology, v. 282, p. 102-117.

Van Rooij, D., Hebbeln, D., Comas, M., Vandorpe, T., Delivet, S., and the MD194 shipboard scientists, EuroFLEETS Cruise Summary Report "MD194 GATEWAY", Cádiz (ES) - Lissabon (PT), 10 21 June 2013, Ghent University, Belgium, 214 p.

Vergnaud-Grazzini, C., and Pierre, C., 1991, High fertility in the Alboran Sea since the Last Glacial Maximum: Paleoceanography, v. 6 , p. $519-536$.

Vergnaud-Grazzini, C., Caralp, M., Faugères, J.-C., Gonthier, E., Grousset, F., Pujol, C., and Saliège, J. F., 1989, Mediterranean outflow through the Strait of Gibraltar since 18000 years B.P.: Oceanologica Acta, v. 12, p. 305-324.

La Violette, P. E., 1984, The advection of cyclic submesoscale thermal features in the Alboran Sea Gyre: Journal of Physical Oceanography, v. 14 , p. $550-565$.

La Violette, P. E., 1986, Short term measurements of surface currents associated with the Alboran Sea during Donde Va?: Journal of Physical Oceanography, v. 16, p. 262-279.

Wang, P., and Chappell, J., 2001, Foraminifera as holocene environmental indicators in the South Alligator River, north Australia: Quaternary International, v. 83, p. 47-62.

Ward, B. L., 1987, Schakoinella antarctica, a new species of Foraminiferida (Glabratellidae): New Zealand Journal of Marine and Freshwater Research, v. 21, p. 621-625.

Weinhandl, R., 1958, Schakoinella, eine neue Foraminiferengattung: K.K. geologische Reichenstalt (Bundesanstalt), Verhandlungen, p. $141-142$.

Wienberg, C., Hebbeln, D., Fink, H. G., Mienis, F., Dorschel, B., Vertino, A., López Correa, M., and Freiwald, A., 2009, Scleractinian cold-water corals in the Gulf of Cádiz - first clues about their spatial and temporal distribution: Deep-Sea Research Part I: Oceanographic Research Papers, v. 56, p. 1873-1893. 